Article

\title{
Enhancing Risk Management by Partnering in International EPC Projects: Perspective from Evolutionary Game in Chinese Construction Companies
}

\author{
Yujing Yang ${ }^{1,2}$, Wenzhe Tang ${ }^{2, *} \mathbb{1}$, Wenxin Shen ${ }^{2}$ and Tengfei Wang ${ }^{2}$ \\ 1 Department of Civil Engineering, Shanxi University, Taiyuan 030006, China; yujingzhenyang@163.com \\ 2 Institute of Project Management and Construction Technology, State Key Laboratory of Hydroscience and \\ Engineering, Tsinghua University, Beijing 10084, China; wenxinshen92@126.com (W.S.); \\ wtf8459@163.com (T.W.) \\ * Correspondence: twz@mail.tsinghua.edu.cn
}

Received: 20 August 2019; Accepted: 23 September 2019; Published: 27 September 2019

\begin{abstract}
Research on risk management in Engineering-Procurement-Construction (EPC) projects has received increasing attention. It is essential to integrate the resources of all participants into the risk management process optimally from the perspective of evolutionary games. The conceptual risk management model in the delivery of international EPC projects is developed in the study. Based on the data from an industry survey, the model has been validated. The path analysis shows that partnering not only directly contributes to interface management and risk management, thereby improving project outcomes, but also has a positive impact on risk management through enhanced interface management. The case study illustrates how partnering has a close linkage with interface management and risk management to achieve superior project performance, confirming the analysis of evolutionary game. The results suggest that contractors' success in applying partnership can play an exemplary role for other contractors, and governments can create a favorable environment to stimulate participants using win-win philosophy for better infrastructure development.
\end{abstract}

Keywords: partnering; risk management; interface management; evolutionary game; project performance; international EPC project

\section{Introduction}

The Engineering-Procurement-Construction (EPC) approach is widely used in current international engineering contracting and has been actively advocated and promoted in the construction market. It involves a set of participants in the process of project delivery, such as clients, contractors, and designers, who have a specific interest in project performance [1]. However, there are limited numbers of companies that can complete the EPC task only relying on their own capacities [2]. Most of EPC contractors are construction companies, e.g., the strength of Chinese EPC contractors is mainly in construction [3]. It is challenging for contractors to deal with complicated EPC interfaces and project risks on their own capabilities due to uncertainties and complex processes in the international EPC market [4,5]. A large number of researchers suggest that partnering strategy which based on a win-win philosophy can promote cooperation between participants to improve risk management [6].

Risk management occupies an important position in the process of project delivery [7] and decision-making processes in delivery of international EPC projects [8-13]. Despite the agreement on partnering's importance to risk management, few studies have systematically demonstrated the causal 
relationships on how partnering associated with risk management in generating improved project outcomes [14].

Therefore, the aim of this research is to reveal an interdisciplinary link between partnering, risk management, interface management and project performance by establishing a conceptual model, which provides a structure that reveals causal relationships among them from the perspective of evolutionary game.

\section{Literature Review}

\subsection{Partnering in International Projects}

Partnering principles have been introduced to improve project delivery efficiency in the construction industry [15]. It is crucial for contractors to use a partnering approach in pursuing international competitive advantages and manage their relationships with stakeholders properly because they need to handle complex relationships to deal with the risks in projects [16]. For instance, partnering helps fully understand the expectations and requirements of clients, and seeks common goals while ensuring the efficiency of EPC project delivery. Partnership using well-defined risk/reward allocations can provide participants with strong motivations and the resources necessary to achieve EPC project goals $[2,17,18]$.

Contractors can establish partnership relationships with other participants to facilitate open communication for integration of the necessary information efficiently. To construct partnering relationships with participants in delivery of EPC projects, contractors need to increase their level of application of partnering CSFs, such as attitudinal factors (common objective, commitment, fairness, attitude and trust) and open communication factors (openness, effective communication, team building, problem resolving and timely response), thereby facilitating sharing ideas, information, knowledge and technology among participants for improving interface management and risk management [15].

\subsection{Interface Management}

Interface management is an approach that can mitigate the adverse influence of complexity in projects, and excellent interface management can assist in avoiding the time delays and excessive rework in the process of construction in EPC projects [19,20]. Construction Industry Institute [21] has defined the interface management as the "management of communications, relationships, and deliverables among two or more interface stakeholders". Inaccurate design, construction and approval processes involving a variety of stakeholders in the international EPC projects increase the difficulties and complexities in interface management [22,23].

\subsection{Risk Management}

Construction is a competitive and risky business. The risk of the contractor is getting higher and higher while participants are working hard on the EPC Turnkey agreement [24]. It is explored the risk path of Chinese contractors in international EPC projects and indicated that the risks can have great impact on project performance [25]. Risks are complex in the delivery of international EPC projects because of the dynamic characteristics affected by the changing international environment [26]. EPC project risk involves a series of participants with specific and important interests in the project outcome. The individual values, willpower, and goal expectations of the stakeholders will jointly determine the characteristics of the management process [27].

EPC contractors need to properly manage various related activities when dealing with risks [28]. Management of risks in international EPC projects is a challenging task, which aims to prevent losses arising from external environment and project implementation [29]. Previous literature has shown that the processes of risk management mainly relies on sufficiency of information [30], and complete information is especially important for improving the contractor's ability to be systematic and proactive in solving problems in a timely manner. It is valuable for contractors to establish partnerships 
with project participants, aiming at facilitating risk management by integrating various information from stakeholders.

Researchers revealed the importance of partnering in strengthening risk management, and partnering can leverage internal and external information to achieve more collaboration and integrated risk management processes between participants, therefore promoting project performance [1,31-33].

\section{Establishment of Conceptual Model in delivering EPC projects}

\subsection{Evolutionary Game in International EPC Projects}

Motivated by the literature described and the theory analysis forward, an evolutionary game is constructed to improve the partnership among stakeholders. Assumptions are that there is an $\mathrm{N}$ international engineering market competition of the enterprises' (the contractors and other stakeholders, which represents one of the other participants in the EPC project market, such as clients, designers and so on) investment opportunities, every enterprise makes decisions independently, and has three strategies of partnering, cooperative and competitive. In international markets, contractors have a ratio of $p_{1}$ to select the strategy of partnering, a ratio of $p_{2}$ to select the strategy of cooperative and a ratio of $P_{3}$ to select the strategy of competitive. The other stakeholders have a ratio of $r_{1}$ to select the strategy of partnering, a ratio of $r_{2}$ to select the strategy of cooperative and a ratio of $r_{3}$ to select the strategy of competitive during the period of $t$, and satisfies the conditions which are $p_{1}+p_{2}+p_{3}=1$ and $r_{1}+r_{2}+r_{3}=1$. Table 1 shows parameter description of model and Table 2 demonstrates payoff matrix of three-dimensional evolutionary game.

Table 1. Parameter description of model.

\begin{tabular}{cc}
\hline Parameters & Description \\
\hline$a$ & Gains of contractors taking the strategy of competitive \\
$m$ & Additional gains of contractors due to take the strategy of cooperative \\
$b$ & Additional gains of contractors due to carry out partnering \\
$n$ & Gains of other stakeholders taking the strategy of competitive \\
$d$ & Additional gains of other stakeholders due to take the strategy of cooperative \\
$s_{1}$ & Additional gains of other stakeholders due to carry out partnering \\
$s_{2}$ & Subsidies or bonuses of government for cooperative \\
\hline
\end{tabular}

Table 2. Payoff matrix of three-dimensional evolutionary game model.

\begin{tabular}{|c|c|c|c|c|}
\hline \multirow{5}{*}{ Contractors } & \multicolumn{4}{|c|}{ Other Stakeholders } \\
\hline & & Partnering & Cooperative & Competitive \\
\hline & Partnering & $\begin{array}{c}a+m+c+s_{2} \\
b+n+d+s_{2}\end{array}$ & $\begin{array}{c}a+m+c+s_{2} \\
b+n+s_{1}\end{array}$ & $\begin{array}{c}a+m+c+s_{2} \\
b\end{array}$ \\
\hline & Cooperative & $\begin{array}{c}a+m+s_{1} \\
b+n+d+s_{2}\end{array}$ & $\begin{array}{c}a+m+s_{1} \\
b+n+s_{1}\end{array}$ & $\begin{array}{c}a+m+s_{1} \\
b\end{array}$ \\
\hline & Competitive & $\begin{array}{c}a ; \\
b+n+d+s_{2}\end{array}$ & $\begin{array}{c}a ; \\
b+n+s_{1}\end{array}$ & $\begin{array}{l}a \\
b\end{array}$ \\
\hline
\end{tabular}

Firstly, the gains of contractors that take the strategy of partnering is:

$$
U_{21}=r_{1}\left(a+m+c+s_{2}\right)+r_{2}\left(a+m+c+s_{2}\right)+r_{3}\left(a+m+c+s_{2}\right)
$$

the gains of contractors that take the strategy of cooperative is:

$$
U_{22}=r_{1}\left(a+m+s_{1}\right)+r_{2}\left(a+m+s_{1}\right)+r_{3}\left(a+m+s_{1}\right)
$$


and the gains of contractors taking the strategy of competitive is calculated as:

$$
U_{23}=r_{1} a+r_{2} a+r_{3} a
$$

The average expected return for the contractors in the international projects is:

$$
\begin{aligned}
& \overline{U_{2}}=p_{1} U_{21}+p_{2} U_{22}+p_{3} U_{23} \\
& =p_{1}\left[r_{1}\left(a+m+c+s_{2}\right)+r_{2}\left(a+m+c+s_{2}\right)+r_{3}\left(a+m+c+s_{2}\right)\right] \\
& +p_{2}\left[r_{1}\left(a+m+s_{1}\right)+r_{2}\left(a+m+s_{1}\right)+\left(1-r_{1}-r_{2}\right)\left(a+m+s_{1}\right)\right] \\
& +p_{3}\left[r_{1} a+r_{2} a+\left(1-r_{1}-r_{2}\right) a\right]
\end{aligned}
$$

The dynamic equation of contractors for take the strategy of partnering can be calculated as:

$$
\begin{aligned}
& F\left(p_{1}\right)=\frac{d p_{1}}{d t}=p_{1}\left(U_{21}-\overline{U_{2}}\right)=r_{2} U_{12}-r_{2} \overline{U_{1}} \\
& =p_{1}\left(a+m+c+s_{2}\right)-p_{1}\left[p_{1}\left(a+m+c+s_{2}\right)+p_{2}\left(a+m+s_{1}\right)+\left(1-p_{1}-p_{2}\right) a\right] \\
& =p_{1}\left(a+m+c+s_{2}\right)-p_{1}\left[p_{1}\left(m+c+s_{2}\right)+p_{2}\left(m+s_{1}\right)+a\right] \\
& =p_{1}\left(m+c+s_{2}\right)-p_{1}\left[p_{1}\left(m+c+s_{2}\right)+p_{2}\left(m+s_{1}\right)\right]
\end{aligned}
$$

\begin{tabular}{|c|c|c|c|c|c|}
\hline \multicolumn{6}{|c|}{ (1) $p_{1}=0, F^{\prime}\left(p_{1}=0\right)=m+c+s_{2}-p_{2}\left(m+s_{1}\right)$} \\
\hline (a) & $m+s_{1} \geq 0$ & $p_{2}<\frac{m+c+s_{2}}{m+s_{1}}$ & $F^{\prime}\left(p_{1}=0\right)>0$ & $F^{\prime}\left(p_{1}=1\right)<0$ & $p_{1}^{*}=1$ \\
\hline (b) & $m+s_{1}<0$ & $p_{2}>\frac{m+c+s_{2}}{m+s_{1}}$ & $F^{\prime}\left(p_{1}=0\right)>0$ & $F^{\prime}\left(p_{1}=1\right)<0$ & $p_{1}^{*}=1$ \\
\hline (c) & $m+s_{1} \geq 0$ & $p_{2}>\frac{m+c+s_{2}}{m+s_{1}}$ & $F^{\prime}\left(p_{1}=1\right)<0$ & & $p_{1}^{*}=0$ \\
\hline (d) & $m+s_{1}<0$ & $p_{2}<\frac{m+c+s_{2}}{m+s_{1}}$ & $F^{\prime}\left(p_{1}=1\right)<0$ & & $p_{1}^{*}=0$ \\
\hline \multicolumn{6}{|c|}{ (2) $p_{1}=1, F^{\prime}\left(p_{1}=1\right)=-\left(m+c+s_{2}\right)-p_{2}\left(m+s_{1}\right)$} \\
\hline (e) & $m+s_{1} \geq 0$ & $p_{2}<-\frac{m+c+s_{2}}{m+s_{1}}$ & $F^{\prime}\left(p_{1}=1\right)>0$ & $F^{\prime}\left(p_{1}=0\right)<0$ & $p_{1}^{*}=0$ \\
\hline (f) & $m+s_{1}<0$ & $p_{2}>-\frac{m+c+s_{2}}{m+s_{1}}$ & $F^{\prime}\left(p_{1}=1\right)>0$ & $F^{\prime}\left(p_{1}=0\right)<0$ & $p_{1}^{*}=0$ \\
\hline (g) & $m+s_{1} \geq 0$ & $p_{2}>\frac{m+c+s_{2}}{m+s_{1}}$ & $F^{\prime}\left(p_{1}=1\right)<0$ & & $p_{1}^{*}=1$ \\
\hline (h) & $m+s_{1}<0$ & $p_{2}<-\frac{m+c+s_{2}}{m+s_{1}}$ & $F^{\prime}\left(p_{1}=1\right)<0$ & & $p_{1}^{*}=1$ \\
\hline
\end{tabular}

Derivation can be expressed as:

$$
\begin{aligned}
& F^{\prime}\left(p_{1}\right)=\left(m+c+s_{2}\right)-\left\{\left[p_{1}\left(m+c+s_{2}\right)+p_{2}\left(m+s_{1}\right)\right]+p_{1}\left(m+c+s_{2}\right)\right\} \\
& =\left(m+c+s_{2}\right)-\left[2 p_{1}\left(m+c+s_{2}\right)+p_{2}\left(m+s_{1}\right)\right]
\end{aligned}
$$

The analysis and signification for contractors in international projects can be detailed in Table 3 as follows:

Table 3. Path analysis of evolutionary game.

The result shows that when the additional benefits of contractors and subsidies from the government are greater than the cost due to adopting the strategy of partnering, and the probability of a contractor taking the strategy of cooperative satisfies the condition of $p_{2}<\frac{m+c+s_{2}}{m+s_{1}}$ and more and more contractors adopt a partnering principle in international projects. Table 3 shows the evolution results of the evolutionary game under different evolution conditions. Whether the contractors in the international project markets take the strategy of the partnership lies on the initial profit value of the contractors and the initial proportion of taking the strategic partnership in the evolutionary game.

\subsection{Conceptual Risk Management Model}

Owing to dynamic variables affected by the intricate environment in the international construction market, it is necessary to improve and strengthen the ability of contractors' risk management by 
partnering with stakeholders [34]. Partnering can help contractors become an open communication system allowing increased information to be efficiently disseminated among stakeholders, which facilitates interface management and risk management for improving EPC project outcomes [15,35]. In addition, few previous publications have focused on the interface management associated with the construction of the partnering model to explore the evolution trend of evolutionary games in the delivery of international EPC projects. Therefore, a model has been built to understand the causality among partnerships, risk management, interface management and project performance in international EPC project delivery as presented in Figure 1.

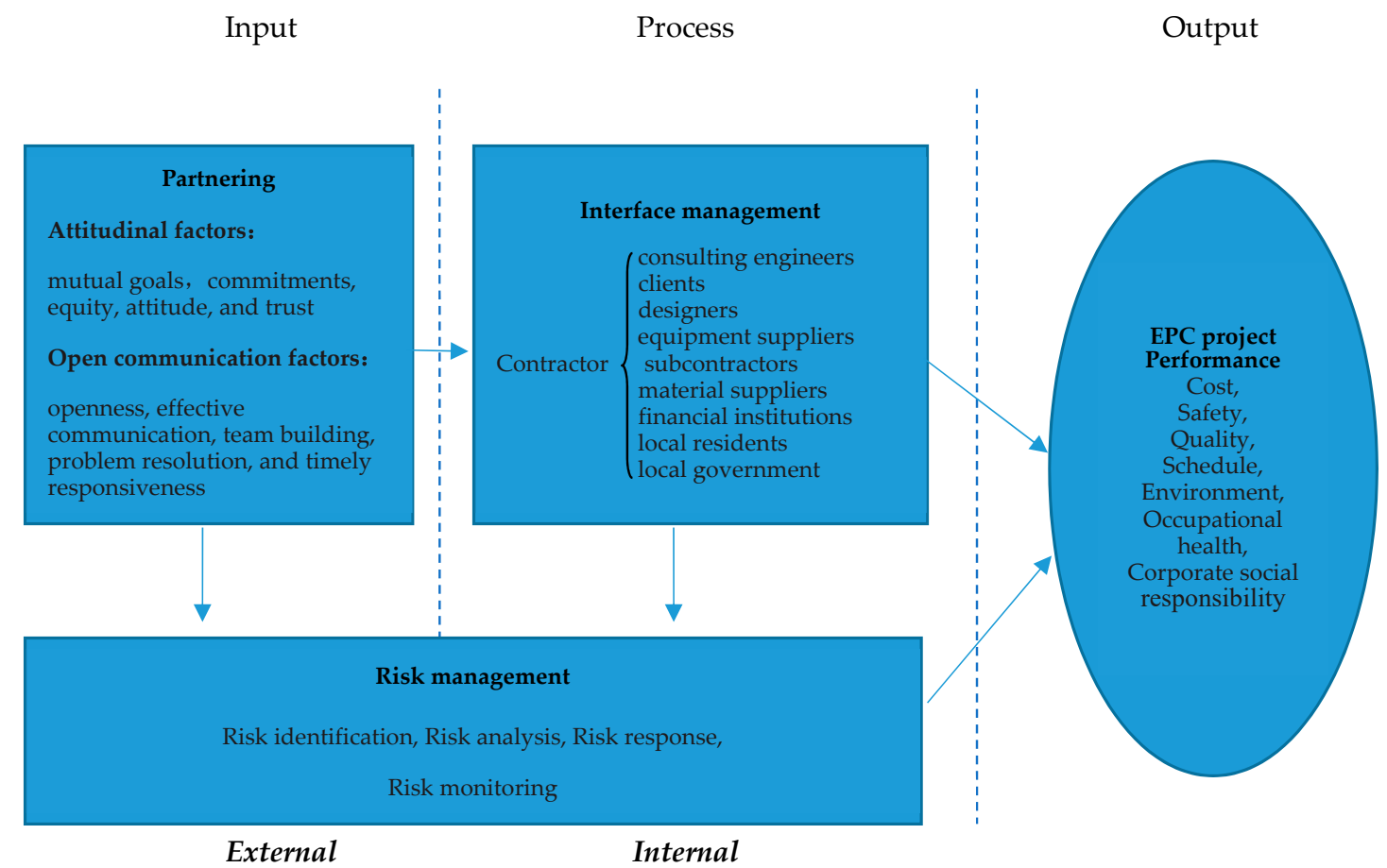

Figure 1. Conceptual risk management model in Engineering-Procurement-Construction (EPC) projects.

The key issues generated by this model (see Figure 1) have been transferred to the following empirical questions:

- What is the current status of partnering, interface management, and risk management in international EPC projects?

- What is the ultimate performance of the EPC projects?

- What are the interrelationships among the above themes?

\section{Methodology}

\subsection{Data Collection Using Triangulated Approach}

Triangulation can be conducive to understanding research statements with qualitative and quantitative data collection [36]. Questionnaire surveys are conducted through fieldwork to avoid the bias of postal survey [37]. Sixty-four questionnaires were sent and received via field trip survey. All respondents have rich experience and play important roles in the EPC projects such as project managers, which ensures the data set is highly reliable and representative.

The results of the study were further explained and verified through interviews and a case study. Field research allows for a follow-up interview immediately after questionnaires are completed. All the interviewed respondents are with senior positions such as project managers, and the interview results help interpretation of the questionnaire survey outcomes. Venezuela's natural gas power station was 
selected for the case study because of the contractor's successful application of the partnering strategy to risk management.

\subsection{Data Analysis Techniques}

The data collected from the questionnaire is analyzed with the assistance of Statistical Package for the Social Sciences (SPSS 22.0).

The techniques suitable for this study are as follows:

- Estimation of the sample mean;

- Rank cases;

- Reliability test;

- Path analysis;

- Case study.

Cronbach's $\alpha$ was adopted to test the internal consistency (reliability), with the barriers $0.7 \leq \alpha \leq 0.8$ (acceptable), $0.8 \leq \alpha \leq 0.9$ (good), and $\alpha \geq 0.9$ (excellent).

Path analysis is adopted to verify the intermediation between partnering, risk management, interface management, and project outcomes. It is considered that the correlation analysis method can be used to reveal the linear projection law between two sets of multidimensional variables, which is to further explain the causality in the model [38].

\section{Survey Results and Analysis}

\subsection{Partnering}

Respondents were invited to rate the performance of partnering between contractors and other stakeholders on a Likert scale 1 (very poor) to 10 (very good), with the result shown in the second column in Table 4.

Table 4. Performance of partnering between contractors and other stakeholders.

\begin{tabular}{cccc}
\hline Partnering with Stakeholders & Rank & Rating & Cronbach's $\alpha$ \\
\hline Contractors-equipment suppliers & 1 & 7.90 & 0.925 \\
Contractors-clients & 2 & 7.86 & \\
Contractors-material suppliers & 3 & 7.76 & \\
Contractors-designers & 4 & 7.68 & \\
Contractors-financial institutions & 5 & 7.52 & \\
Contractors-subcontractors & 6 & 7.50 & \\
Contractors-consulting engineers & 7 & 7.48 & \\
Contractors-local residents & 8 & 7.32 & \\
Contractors-local government & 9 & 6.92 & \\
\hline Average & & 7.55 & \\
\hline
\end{tabular}

Referring to Table 4, Cronbach's alpha value for the degree of partnering between different stakeholders is 0.925 , indicating the internal consistency reliability of the data is good. According to Table 4, the most important relationships are with suppliers and clients, and this is because equipment and material suppliers are located upstream of the supply chain, providing equipment and materials which can decide the quality of EPC projects. The relationships between the contractors and clients obtain the score of 7.86, ranking the second, because trust-based relationship is critical for the clients to award the contracts to the contractor. The score between the contractors and subcontractors is 7.50, which is because the local subcontractors can effectively solve problems related to insufficient workforce and reduce construction cost. Maintaining a good partnership with subcontractors is important to ensure the successful delivery of projects. 


\subsection{Interface Management}

Respondents were invited to evaluate the frequency of problems for contractors on a ten-point Likert scale, ranging from 1 (never happens) to 10 (always happens). The results are tabulated in Table 5.

Table 5. Frequency of interface problems between stakeholders.

\begin{tabular}{cccc}
\hline Partnering with Stakeholders & Rank & Rating & Cronbach's $\alpha$ \\
\hline Contractors-consulting engineers & 1 & 6.98 & 0.915 \\
Contractors-clients & 2 & 6.50 & \\
Contractors-designers & 3 & 6.48 & \\
Contractors-equipment suppliers & 4 & 6.18 & \\
Contractors-subcontractors & 5 & 6.14 & \\
Contractors -material suppliers & 6 & 5.90 & \\
Contractors-financial institutions & 7 & 5.84 & \\
Contractors-local residents & 8 & 5.66 & \\
Contractors-local government & 9 & 5.52 & \\
\hline Average & & 6.14 & \\
\hline
\end{tabular}

The reliability analysis results show Cronbach's alpha value for the frequency of interface problems is 0.915 , indicating good internal consistency and reliability. It can be seen from Table 5 that the efficiency of interface problems occurred between the contractors and the consulting engineers obtain the highest score, followed by clients, designers, equipment suppliers, sub-contractors. There are lots of interfaces between contractors and consulting engineers; this is largely attributed to the fact that the contractors' work needs to be approved by the consulting engineers, covering different kinds of jobs such as civil engineering, and electrical and mechanical engineering.

Respondents were asked to evaluate the performance of interfacing management between the contractors and the stakeholders on a ten-point Likert scale, ranging from 1 (very poor) to 10 (very good) and the results are listed in Table 6.

Table 6. Performance of interface management between the contractors and the stakeholders.

\begin{tabular}{cccc}
\hline & Rank & Rating & Cronbach's $\alpha$ \\
\hline Contractors-designers & 1 & 8.04 & 0.912 \\
Contractors-equipment suppliers & 2 & 7.90 & \\
Contractors-material suppliers & 3 & 7.82 & \\
Contractors-subcontractors & 4 & 7.76 & \\
Contractors-consulting engineers & 5 & 7.38 & \\
Contractors-clients & 6 & 7.28 & \\
Contractors-financial institutions & 7 & 6.80 & \\
Contractors-local government & 8 & 6.58 & \\
Contractors-local residents & 9 & 6.42 & \\
\hline Average & & 7.46 & \\
\hline
\end{tabular}

As shown in Table 6, the average indicator rating is 7.46, Cronbach's alpha value for interface management performance is 0.912 , indicating the internal consistency reliability of the data is good [39]. As detailed in Table 6, interface management performance between EPC contractors and designers is the best, which is attributed to the fact that designers can determine the cost of EPC projects to a large extent. Equitable sharing rewards between the contractor and the designer from value engineering is important to promote design optimization. Interviews indicate that the contractors who provide additional resources for the designers on in-depth value analysis will obtain significant returns from design optimizing. 


\subsection{Risk Management}

To investigate the importance of different risks in international EPC projects, respondents were invited to rate the risks on a ten-point Likert scale, ranging from 1 (a negligible risk) to 10 (an extreme risk) and the results are tabulated in Table 7. This analysis methodology is a checklist analysis and expert judgment composed of senior project managers responsible for projects in the relevant areas [40].

As results presented in Table 7, the average indicator rating is 5.87, Cronbach's alpha value for the importance of risks in international EPC projects is 0.915 , indicating there is a good level of internal data consistency. As Table 7 shows, EPC project risks cover broad themes, mainly regarding economic risks, client related risks, design risks, contractor's technical capabilities, procurement risks, HSE, political risks, poor project planning, and adversarial natural environment.

In order to investigate the risk management level of the EPC contractors, respondents were invited to assess the frequency of risk management techniques applied by rating them on a ten-point Likert scale, ranging from 1 (least frequently used) to 10 (most frequently used) and the results are listed in Table 8.

Table 7. Importance of risks in international EPC projects.

\begin{tabular}{|c|c|c|c|}
\hline Risks & Rank & Rating & Cronbach's $\alpha$ \\
\hline Exchange rate/inflation risk & 1 & 7.14 & 0.915 \\
\hline Clients' payment delay & 2 & 6.94 & \\
\hline Contractor's incompetent technology & 2 & 6.94 & \\
\hline Project financing difficulties & 4 & 6.90 & \\
\hline Inefficient processing of client & 5 & 6.72 & \\
\hline Design errors and defects & 5 & 6.72 & \\
\hline Cost control in project implementation & 7 & 6.58 & \\
\hline Quality of work & 7 & 6.58 & \\
\hline Delay of approval from the client & 9 & 6.56 & \\
\hline Force majeure & 9 & 6.56 & \\
\hline Lack of required material and equipment & 11 & 6.52 & \\
\hline Delay of design approval from consultant & 12 & 6.48 & \\
\hline Price change of material and equipment & 13 & 6.44 & \\
\hline Confiscation of the bid guarantee & 13 & 6.44 & \\
\hline Unstable political situation in the host country & 15 & 6.38 & \\
\hline Material or equipment quality & 16 & 6.36 & \\
\hline Incompetence of subcontractors & 17 & 6.34 & \\
\hline Poor economic environment & 18 & 6.28 & \\
\hline Inappropriate design option & 19 & 6.24 & \\
\hline Lack of design optimization & 20 & 6.14 & \\
\hline Change in laws and regulations & 21 & 6.10 & \\
\hline HSE & 21 & 6.10 & \\
\hline Corruption & 21 & 6.10 & \\
\hline Logistics & 24 & 6.08 & \\
\hline Expropriation and nationalization of assets & 25 & 6.04 & \\
\hline Design variation & 25 & 6.04 & \\
\hline Change of quantity & 27 & 6.00 & \\
\hline Insurance is not sufficient & 27 & 6.00 & \\
\hline Adversarial natural environment & 29 & 5.96 & \\
\hline Inconvenient local business trading & 29 & 5.96 & \\
\hline Shortage of labor, materials and equipment & 31 & 5.94 & \\
\hline Inappropriate allocation of risks and rewards & 32 & 5.90 & \\
\hline Work injury accident & 32 & 5.90 & \\
\hline Restrictions from laws and regulations & 34 & 5.86 & \\
\hline The existence of terrorism & 34 & 5.86 & \\
\hline Insufficient project planning & 36 & 5.80 & \\
\hline
\end{tabular}


Table 7. Cont.

\begin{tabular}{cccc}
\hline Risks & Rank & Rating & Cronbach's $\alpha$ \\
\hline Unclear design intention & 36 & 5.80 & \\
Natural hazards & 38 & 5.76 \\
Contractors' opportunism behaviors & 38 & 5.76 \\
Inappropriate construction planning & 40 & 5.66 \\
Poor relations among project participants & 41 & 5.62 \\
Tense relationship between host country and the & 42 & 5.60 \\
contractor's home country & 43 & 5.48 \\
Damage of construction plants & 43 & 5.48 \\
Incomplete local legal system & 43 & 5.48 \\
Poor local transportation & 46 & 5.44 \\
Poor construction condition at site & 47 & 5.16 \\
Confliction with local communities & 48 & 5.06 \\
Difficulties in land acquisition and resettlement & & \\
of migration & & 5.87 \\
\hline Average & &
\end{tabular}

Table 8. Application level of risk management techniques.

\begin{tabular}{cccc}
\hline Techniques of Risk Management & Rank & Rating & Cronbach's $\alpha$ \\
\hline Risk identification & & & 0.906 \\
Brainstorming & 1 & 8.10 & \\
Consulting experts & 14 & 7.16 & \\
Checklist & 15 & 7.02 & \\
Individual assessment & 17 & 6.22 & \\
Risk analysis & & \\
Joint evaluation of key participants & 3 & 7.90 \\
Qualitative analysis & 8 & 7.50 \\
Use of consulting experts & 12 & 7.26 \\
Semi-quantitative analysis & 13 & 7.20 \\
Quantitative analysis & 16 & 6.70 \\
Individual analysis & 17 & 6.22 \\
Use of computers and other modeling methods & 20 & 4.92 \\
\hline Risk response & & \\
Reduce the likelihood of occurrence & 2 & 8.00 \\
Avoid the risk & 4 & 7.86 \\
Transfer the risk & 7 & 7.54 \\
Reduce the consequences & 11 & 7.40 \\
Retain the risk & 19 & 5.62 \\
\hline Risk monitoring & & \\
Periodic document reviews & 5 & 7.82 \\
Periodic risk reporting & 6 & 7.68 \\
Periodic trend reporting & 8 & 7.50 \\
Avtablishment of the risk warning system & 7.50 \\
\hline
\end{tabular}

As shown in Table 8, the average indicator rating is 7.16, Cronbach's alpha value for the application level of risk management techniques is 0.906 , indicating good internal consistency reliability. In risk identification, "brainstorming" is the most used technique, "checklist" and "consulting experts" follow, and "individual assessment" is the least used. In risk analysis, "joint evaluation of key participants" is the most frequently used technique in risk management. The "use of computers and other modeling methods" is the least frequently used technique, owing to high requirements for modeling and difficulty in collecting quantifiable data. 
In risk response, the score of "reduce the likelihood of occurrence" is 8.00 , which is the most frequently used method in EPC projects for contractors. This reflects that the EPC contractors tend to take proactive prevention risk mitigation strategies. In risk monitoring, "periodic document reviews" and "periodic risk reporting" are used more frequently than "establishment of the risk warning system" and "periodic trend reporting". Generally speaking, qualitative risk management methods frequently use quantitative analysis techniques.

In order to better understand the obstacles of risk management, the factors that might affect the level of risk management were further investigated. The respondents were asked to rate the barriers to risk management on a ten-point Likert scale, ranging from 1 (least important barrier) to 10 (most important barrier). The results are listed in Table 9.

Table 9. Barriers to risk management.

\begin{tabular}{cccc}
\hline Factors Affecting Risk Management & Rank & Rating & Cronbach's $\alpha$ \\
\hline Lack of formal risk management system & 1 & 8.24 & 0.949 \\
Lack of joint risk management mechanism by parties & 2 & 8.20 & \\
Lack of awareness for joint risk management & 3 & 8.10 & \\
Lack of cooperative risk management knowledge and skills & 4 & 7.94 & \\
Ineffective risk monitoring & 5 & 7.90 \\
Lack of historical data for risk analysis & 6 & 7.62 \\
Inappropriate risk allocation & 7 & 7.40 \\
Different understanding of risks among project participants & 7 & 7.40 \\
Lack of ongoing project information for decision-making & 9 & 7.38 \\
Lack of incentives for better risk management & 10 & 7.12 & \\
Ineffective implementation of risk control strategy & 11 & 6.48 & \\
Average & & 7.60 \\
\hline
\end{tabular}

As is shown in Table 9, the average indicator rating is 7.60, and Cronbach's alpha value for the barriers to risk management is 0.949 , indicating the data has a good internal consistency reliability. The score of "lack of formal risk management system", "lack of joint risk management mechanisms by parties", "lack of risk awareness for joint management" and "lack of cooperative risk management knowledge and skills" are the top four barriers for risk management. This demonstrates that it is indispensable for project participants to establish a partnering-based risk management system to collaboratively deal with various EPC project risks. Partnering also can help participants share both historical data and ongoing project information to support decision making regarding risk management.

\section{Project Performance}

The project performance of quality, safety, schedule, occupational health, cost, environment, and corporate social responsibility is rated on a ten-point Likert scale, ranging from 1 (very poor) to 10 (very good). The results are listed in Table 10.

Referring to Table 10, Cronbach's alpha value for the project performance in international EPC projects is 0.821 , suggesting a good internal consistency reliability of data. The average indicator rating is 7.94, showing that the performances of the EPC project are satisfactory. However, cost obtained the lowest rating, reflecting that achieving financial related objectives is challenging for EPC contractors. This is largely attributed to the fact that the contractors take most of project risks, e.g., different from in DBB projects, the risk of increasing quantity in EPC projects normally is born by the contractors. 
Table 10. Project performance in international EPC projects.

\begin{tabular}{cccc}
\hline Partnering with Stakeholders & Rank & Rating & Cronbach's $\alpha$ \\
\hline Quality & 1 & 8.48 & 0.821 \\
Safety & 2 & 8.18 & \\
Schedule & 3 & 8.00 & \\
Occupational health & 4 & 7.90 & \\
Corporate social responsibility & 5 & 7.82 & \\
Environment & 6 & 7.68 & \\
Cost & 7 & 7.52 & \\
Average & & 7.94 & \\
\hline
\end{tabular}

\section{Testing the Model}

\subsection{Path Analysis}

Path analysis has been conducted to test the relationship among partnering, risk management, interface management and project performance established in the conceptual model as shown in Figure 2.
Input
Process
Output

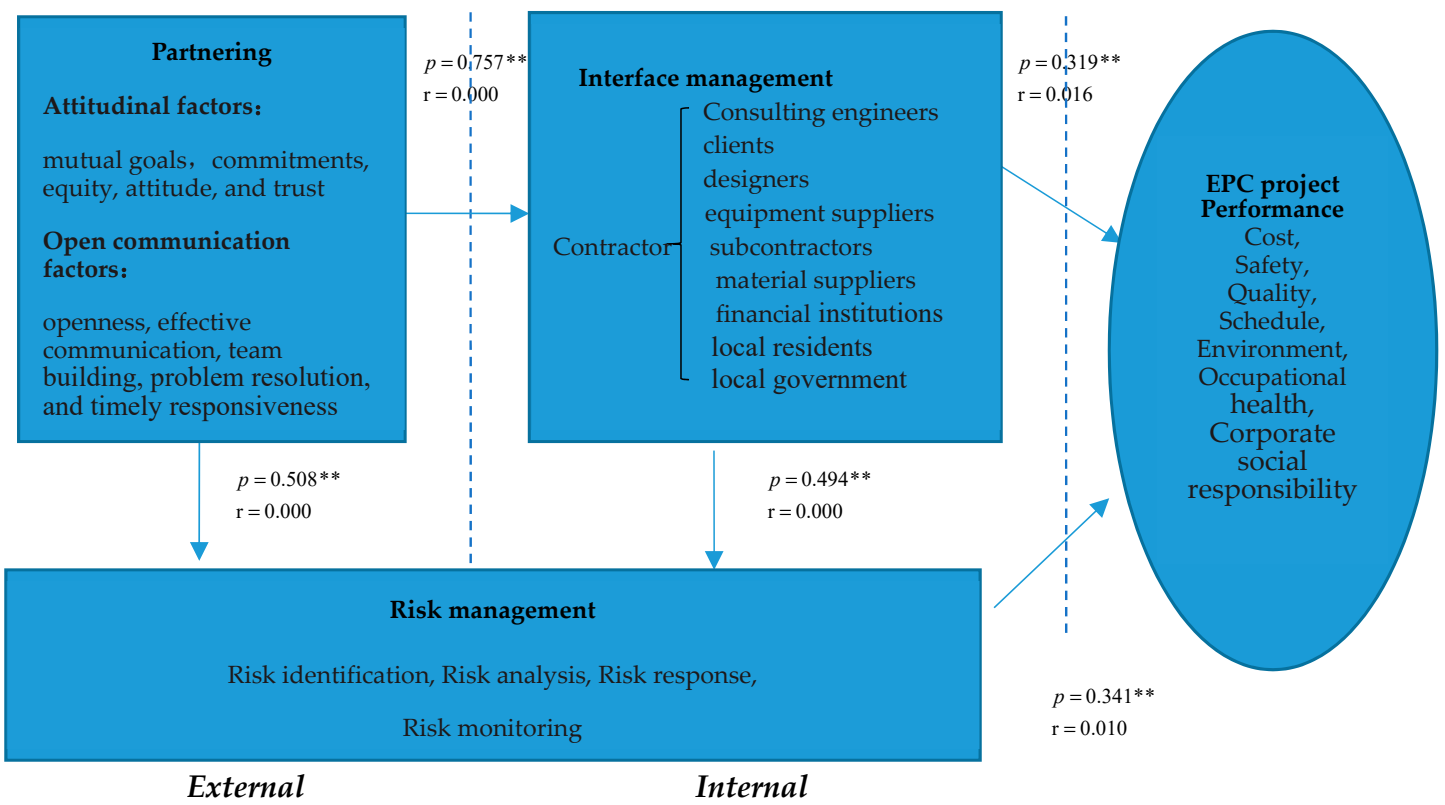

Figure 2. Relationships among partnering, risk management, interface management and EPC project performance. (Note: ${ }^{* *}=$ Correlation is significant at the 0.01 level (2-tailed)).

As shown in Figure 2, the results demonstrate three significant paths:

Path 1: partnering $\longrightarrow$ interface management $\longrightarrow$ project performance;

Path 2: partnering $\longrightarrow$ risk management $\longrightarrow$ project performance;

Path 3: partnering $\longrightarrow$ interface management $\longrightarrow$ risk management $\longrightarrow$ project performance.

The above paths show that partnering not only directly contributes to interface management and risk management, thereby improving project outcomes, but also has an impact on risk management through enhanced interface management. 


\subsection{Relationship between Partnering and Risk Management}

As shown in Figure 2, partnering significantly predicts risk management with the standardized regression coefficient being $0.508(r=0.000)$, verifying the strong impact of partnering on risk management. Partnering can effectively facilitate the use of risk management techniques such as "brainstorming" for risk identification and "joint evaluation of key participants" for risk analysis (see Table 8), which rely on the joint efforts of participants in EPC projects. As for risk barriers (see Table 9), it is appropriate to take the partnering approach to remove the barriers of "lack of joint risk management mechanism by parties", "lack of awareness for joint risk management", "lack of cooperative risk management knowledge and skills", "lack of historical data for risk analysis", "inappropriate risk allocation", "different understanding of risks among project participants", "lack of ongoing project information for decision-making" and "lack of incentives for better risk management".

Partnering with local authorities and communities is critical for contractors to solve political risks such as "unstable political situation in the host country" and "conflict with local communities", and "difficulties in land acquisition and resettlement of migration" (see Table 7). Given that EPC projects typically need a large amount of money, it is essential to have a good partnership with banks, which help manage the financial related risks such "poor economic environment". One approach of the Chinese contractors is assisting the clients in obtaining export credits with the support of governments and banks, which significantly reduces the financial risks such as "clients' payment delay" and "project financing difficulties" (see Table 7). Partnering with material and equipment suppliers and subcontractors is important for reducing risks of such as "material or equipment quality", "price change of material and equipment" and "shortage of labor, materials and equipment" (see Table 7).

\subsection{Relationship between Partnering and Interface Management}

As shown in Figure 2, partnering has a significant impact on interface management with a standardized regression coefficient of $0.757(r=0.000)$, verifying the strong impact of partnering on interface management. Interviews with contractor managers during the site visit indicate that there are lots of changes and conflicts among EPC activities, which can result in a large number of interface problems. Whether these interface problems can be solved efficiently and effectively will significantly affect the implementation of the EPC projects. Trust and open communication in partnering can play an important role in enhancing interface management. For example, some builders and designers establish partnering relationships to conduct a complementary geologic survey to eliminate the key uncertainties in the conceptual design phase, thereby preventing many interface problems during project implementation.

\subsection{Relationship between Interface Management and Risk Management}

As shown in Figure 2, interface management has a significant influence on risk management with the standardized regression coefficient of $0.494(r=0.000)$, verifying the close relationship between interface management and risk management. Interviews confirm that many EPC project risks are caused by poor coordination between interfacing stakeholders, including "design errors and defects", "delay of approval from the client", "lack of design optimization", "design variation", "unclear design intention", "poor relations among project participants", and "inappropriate construction planning"(see Table 7). Interface management approaches such as clearly-defined responsibilities and work procedures among project participants can effectively solve the problems on client and consultant engineer approval, improve design constructability by incorporating contractors' feedbacks, and facilitate preparing plans for equipment and material procurement. In addition, the use of information systems is an important technical support for efficient interface management in EPC projects. 


\subsection{Impacts of Interface Management and Risk Management on Project Performance}

As shown in Figure 2, interface management and risk management are correlated with project outcomes with the standardized regression coefficients being $0.319(r=0.016)$ and $0.341(r=0.010)$ respectively, confirming that interface management and risk management can significantly improve EPC project performance.

The above results show that partnering has a close linkage with interface management and risk management, thereby achieving superior project performance. These relationships illustrated by a case study as below.

\section{Case Study of the Venezuelan Gas Power Station}

\subsection{Project Background}

The natural gas power station project in Venezuela is an EPC project with a contract period of 12 months. This project is invested by the largest oil company in the country, and the development of the project is supported by the local government. The contractor of the project is a Chinese company. In terms of supplier selection, the contractor has a procurement information management system to help select qualified suppliers considering their past performance. The key equipment supplier is the General Electric Company, and the key material suppliers are the local large and medium-sized manufacturers with good credit.

\subsection{Partnering and Interface Management}

In the project, the contractor emphasized partnering and interface management with other stakeholders. The contractor adopts a win-win strategy and strives to establish partnerships with clients which assist in financing and obtaining loans from Import and Export Bank of China, thereby promoting the development of the project.

The contractor formed an alliance with the designer, which clearly allocated the rewards and risks. The EPC project team composed of members from both the contractor and the designer, and the ways of communication and problem solving are clearly defined. These provided a sound base for interface management between these two parties. The designer can effectively integrate the contractor's feedback into the design process, and the contractor can clearly understand the designer's intention in construction, which can improve the constructability of designs and help reduce the risks related to construction.

The contractor has established partnering relationships with local government and communities. The contractor has actively taken part in mitigating the flood risk and sponsoring medical facilitates for local communities.

\subsection{Risk Management}

There are lots of differences in project management between China and Venezuela, especially on the technical standards and institutional environment. For example, the technical standards on some electrical and mechanical devices are different, which could cause quality problems and result in extra cost arising from reworks; there are also differences in languages, laws, social norms, and cultures between Venezuela and China, which caused management difficulties for the contractor in the early stage of project delivery. The main risks of the project are related to design, procurement, inflation, and compliance to local laws and regulations.

To manage the risks of procurement, the contractor has good interfacing with the key suppliers worldwide, which enhances information sharing and efficient decision-making in dealing with equipment design, manufacturing, logistic, installation, and commissioning.

From 2011 to 2015, the rate of inflation was very high due to the changing economic status. To mitigate the financial risk, it is specified in the contract that payment structure is $75 \%$ in US dollars and $25 \%$ in local currency. In addition, the rate of the project advance payment reached to a high rate 
of $50 \%$, which allowed the contractor to purchase the majority of equipment and materials in the early stage of the project, which significantly mitigated the inflation risk.

In dealing with law and regulation related risks, the contractor hired local consultants to help abide requirements on environmental protection, occupational health, safety, and use of local workforce. For example, the contractor employed sufficient local staff and provided training to improve their skills. This not only helped reduce quality and safety related risks but also improved the engagement with local communities, which enhanced the contractor's implementation of social responsibility.

\subsection{Project Outcomes of the Project}

Combing partnering and interface management with risk management, the contractor effectively integrated stakeholder's needs into the delivery processes of the EPC project, thereby successfully achieving the project objectives. The good performance of the contractor won the trust of the stakeholders and improved the reputation in the locality, which helped expand the market share.

The successful delivery of the project by the application of partnering has played an exemplary role for other contractors. The government has also contributed to the success of the project by creating a favorable infrastructure development environment to promote contractors' using partnering approach. These outcomes confirm the evolutionary game results in international EPC projects.

\section{Conclusions}

\subsection{Findings}

According to the data collected from Chinese construction companies in the delivery of international EPC projects, the relationships established in the model (see Figure 1) have been analyzed and confirmed. The main findings of this research are summarized as follows:

1. The survey results have revealed the status of partnering application, interface management, and risk management, suggesting the needs for project participant to cooperatively manage interfacing EPC activities and to jointly deal with various risks during the project delivery.

2. The path analysis show that partnering not only directly contribute to interface management and risk management, thereby improving project outcomes, but also has a positive impact on risk management through enhanced interface management.

3. The case study of the Venezuelan Gas Power Station project illustrates how partnering has a close linkage with interface management and risk management to achieve superior project performance, confirming the analysis of evolutionary game.

4. Contractors' success in applying partnership can play an exemplary role for other contractors, and governments can create a favorable environment to stimulate participants' using win-win philosophy for better infrastructure development.

\subsection{Contributions to the Body of Knowledge}

This study has important contributions on both theory and practice. Firstly, a model on the evolutionary game is constructed to describe the process of the evolutionary game with three different strategies to be taken by participants in international EPC projects. Secondly, this study establishes interdisciplinary links between knowledge areas such as partnering, risk management, interface management, and project outcomes by constructing an intermediary model, demonstrating the causal relationships of the above themes. Thirdly, the survey results provide empirical evidence for understanding the status of partnering application, interface management and risk management, forming a sound base for decision-making in delivering international EPC projects. Fourthly, the above results suggest broad practical strategies for EPC project management improvements. 


\subsection{Limitations and Future Research Directions}

The main limitation of the research lies in the fact that the samples are only from Chinese companies. However, the research background is based on the experience gained from literature worldwide and further research is needed to verify the findings. Future researches should include: (1) how to build partnerships among project participants based on win-win values to achieve project objectives as well as long-term strategic partnership goals; (2) how government can provide stimuli to encourage project participants' cooperatively improving efficiency of the construction industry.

Author Contributions: Y.Y. drafted this paper, W.T. revised the paper, W.S. and T.W. collected and analyzed the data.

Funding: Many thanks are given to the National Natural Science Foundation of China (Grant No. 51579135). Special thanks are also given to the respondents for their generous contributions during the survey.

Conflicts of Interest: The authors declare no conflict of interest.

\section{References}

1. Choudhry, R.M.; Iqbal, K. Identification of risk management system in construction industry in Pakistan. J. Manag. Eng. 2012, 29, 42-49. [CrossRef]

2. Galloway, P. Design-build/EPC contractor's heightened risk-Changes in a changing world. J. Leg. Aff. Disput. Resolut. Eng. Constr. 2008, 1, 7-15. [CrossRef]

3. Corkin, L. Chinese construction companies in Angola: A local linkages perspective. Resour. Policy 2012, 37, 475-483. [CrossRef]

4. Wang, S.; Tang, W.; Li, Y. Relationship between owners' capabilities and project performance on development of hydropower projects in China. J. Constr. Eng. Manag. 2013, 139, 1168-1178. [CrossRef]

5. Zou, P.X.; Chen, Y.; Chan, T.Y. Understanding and improving your risk management capability: Assessment model for construction organizations. J. Constr. Eng. Manag. 2009, 136, 854-863. [CrossRef]

6. Gottlieb, S.C.; Haugbølle, K. Contradictions and collaboration: Partnering in-between systems of production, values and interests. Constr. Manag. Econ. 2013, 31, 119-134. [CrossRef]

7. Jacobsson, M.; Roth, P. Towards a shift in mindset: Partnering projects as engagement platforms. Constr. Manag. Econ. 2014, 32, 419-432. [CrossRef]

8. Kangari, R. Risk management perceptions and trends of US construction. J. Constr. Eng. Manag. 1995, 121, 422-429. [CrossRef]

9. Kartam, N.A.; Kartam, S.A. Risk and its management in the Kuwaiti construction industry: A contractors' perspective. Int. J. Proj. Manag. 2001, 19, 325-335. [CrossRef]

10. Ling, F.Y.Y.; Hoi, L. Risks faced by Singapore firms when undertaking construction projects in India. Int. J. Proj. Manag. 2006, 24, 261-270. [CrossRef]

11. Fang, D.; Li, M.; Fong, P.S.W.; Shen, L. Risks in Chinese construction market-Contractors' perspective. J. Constr. Eng. Manag. 2004, 130, 853-861. [CrossRef]

12. Lyons, T.; Skitmore, M. Project risk management in the Queensland engineering construction industry: A survey. Int. J. Proj. Manag. 2004, 22, 51-61. [CrossRef]

13. Loosemore, M.; McCarthy, C.S. Perceptions of contractual risk allocation in construction supply chains. J. Prof. Issues Eng. Educ. Pract. 2008, 134, 95-105. [CrossRef]

14. Suprapto, M.; Bakker, H.L.; Mooi, H.G. Relational factors in owner-contractor collaboration: The mediating role of teamworking. Int. J. Proj. Manag. 2015, 33, 1347-1363. [CrossRef]

15. Tang, W.; Duffield, C.F.; Young, D.M. Partnering mechanism in construction: An empirical study on the Chinese construction industry. J. Constr. Eng. Manag. 2006, 132, 217-229. [CrossRef]

16. Cooke, F.L. Chinese multinational firms in Asia and Africa: Relationships with institutional actors and patterns of HRM practices. Hum. Resour. Manag. 2014, 53, 877-896. [CrossRef]

17. Palacios, J.L.; Gonzalez, V.; Alarcón, L.F. Selection of third-party relationships in construction. J. Constr. Eng. Manag. 2013, 140, B4013005. [CrossRef]

18. Wang, T.; Tang, W.; Qi, D.; Shen, W.; Huang, M. Enhancing design management by partnering in delivery of international EPC projects: Evidence from Chinese construction companies. J. Constr. Eng. Manag. 2015, 142, 04015099. [CrossRef] 
19. Ahn, S.; Shokri, S.; Lee, S.; Haas, C.T.; Haas, R.C. Exploratory study on the effectiveness of interface-management practices in dealing with project complexity in large-scale engineering and construction projects. J. Manag. Eng. 2016, 33, 04016039. [CrossRef]

20. Shen, W.; Tang, W.; Wang, S.; Duffield, C.F.; Hui, F.K.P.; You, R. Enhancing trust-based interface management in international engineering-procurement-construction projects. J. Constr. Eng. Manag. 2017, 143, 04017061. [CrossRef]

21. CII (Construction Industry Institute). Interface management implementation guideline (IMIGe). In IR Interface Management; University of Texas at Austin: Austin, TX, USA, 2014.

22. Luo, L.; He, Q.; Xie, J.; Yang, D.; Wu, G. Investigating the relationship between project complexity and success in complex construction projects. J. Manag. Eng. 2016, 33, 04016036. [CrossRef]

23. Shokri, S.; Haas, C.T.; GHaas, R.C.; Lee, S.H. Interface-management process for managing risks in complex capital projects. J. Constr. Eng. Manag. 2015, 142, 04015069. [CrossRef]

24. Gu, X.; Geng, Z.; Xu, W.; Zhu, Q. Hierarchy probability cost analysis model incorporate maims principle for epc project cost estimation. Expert Syst. Appl. Int. J. 2011, 38, 8087-8098. [CrossRef]

25. Boateng, P.; Zhen, C.; Ogunlana, S.O. An analytical network process model for risks prioritisation in megaprojects. Int. J. Proj. Manag. 2015, 33, 1795-1811. [CrossRef]

26. Ellinas, G.; Panayiotou, C.; Kyriakides, E.; Polycarpou, M. Critical Infrastructure Systems: Basic Principles of Monitoring, Control, and Security. In Intelligent Monitoring, Control, and Security of Critical Infrastructure Systems; Springer: Berlin/Heidelberg, Germany, 2015; pp. 1-30.

27. Baldry, D. The evaluation of risk management in public sector capital projects. Int. J. Proj. Manag. 1998, 16, 35-41. [CrossRef]

28. Kwak, Y.H.; Smith, B.M. Managing risks in mega defense acquisition projects: Performance, policy, and opportunities. Int. J. Proj. Manag. 2009, 27, 812-820. [CrossRef]

29. Shen, W.; Tang, W.; Yu, W.; Duffield, C.F.; Wei, Y.; Fang, J. Causes of Contractors' Claims in International Engineering-Procurement-Construction Projects. J. Civ. Eng. Manag. 2017, 23, 727-739. [CrossRef]

30. Dikmen, I.; Birgonul, M.T.; Han, S. Using fuzzy risk assessment to rate cost overrun risk in international construction projects. Int. J. Proj. Manag. 2007, 25, 494-505. [CrossRef]

31. Jaafari, A. Management of risks, uncertainties and opportunities on projects: Time for a fundamental shift. Int. J. Proj. Manag. 2001, 19, 89-101. [CrossRef]

32. Ward, S.; Chapman, C. Transforming project risk management into project uncertainty management. Int. J. Proj. Manag. 2003, 21, 97-105. [CrossRef]

33. Choe, S.; Leite, F. Assessing safety risk among different construction trades: Quantitative approach. J. Constr. Eng. Manag. 2016, 143, 04016133. [CrossRef]

34. Du, L.; Tang, W.; Liu, C.; Wang, S.; Wang, T.; Shen, W.; Huang, M.; Zhou, Y. Enhancing engineer-procureconstruct project performance by partnering in international markets: Perspective from Chinese construction companies. Int. J. Proj. Manag. 2016, 34, 30-43. [CrossRef]

35. Chan, A.P.; Chan, D.W.; Fan, L.C.; Lam, P.T.; Yeung, J.F. Achieving partnering success through an incentive agreement: Lessons learned from an underground railway extension project in Hong Kong. J. Manag. Eng. 2008, 24, 128-137. [CrossRef]

36. Garmer, K.; Liljegren, E.; Osvalder, A.L.; Dahlman, S. Arguing for the need of triangulation and iteration when designing medical equipment. J. Clin. Monit. Comput. 2002, 17, 105-114. [CrossRef] [PubMed]

37. Akintoye, A.S.; MacLeod, M.J. Risk analysis and management in construction. Int. J. Proj. Manag. 1997, 15, 31-38. [CrossRef]

38. Hardoon, D.R.; Szedmak, S.; Shawe-Taylor, J. Canonical correlation analysis: An overview with application to learning methods. Neural Comput. 2004, 16, 2639-2664. [CrossRef] [PubMed]

39. Sharma, S. Applied Multivariate Techniques; Wiley: New York, NY, USA, 1996; pp. 116-123.

40. Chen, C.; Iyengar, G.; Moallemi, C.C. An axiomatic approach to systemic risk. Manag. Sci. 2013, 59, $1373-1388$. [CrossRef]

(C) 2019 by the authors. Licensee MDPI, Basel, Switzerland. This article is an open access article distributed under the terms and conditions of the Creative Commons Attribution (CC BY) license (http://creativecommons.org/licenses/by/4.0/). 